\title{
Pediatric Patient with Pars Planitis Associated with Lyme Disease: A Rare Presentation: Case Report
}

\author{
Nurdan ARICAN 國
}

\begin{abstract}
Lyme-associated uveitis is more common in adults, but very rare in children. Ophthalmological symptoms are seen in a minority of Lyme cases. Uveitis is seen in less than $1 \%$ and different clinical features can be seen. For the diagnosis of Lyme-associated uveitis, positive ELISA, immunoblot serology, exclusion of other causes by various tests in differential diagnosis, efficacy of antibiotics after primary resistance to steroid therapy alone, tick bite, living in an endemic area and the presence of systemic clinical symptoms should be investigated. In our report, we aimed to present a very rare Lyme disease-related intermediate uveitis in an 11-year-old male patient who had a history of tick bite 4 months ago and was diagnosed with pars planitis and peripheral retinal vasculitis. Recurrence was observed after being asymptomatic for 6 months after the treatment. However, our case was successfully treated with a new course of antibiotics in addition to steroid therapy.
\end{abstract}

Keywords: Lyme disease; child; intermediate uveitis.

\section{Lyme Hastalığına Bağlı Pars Planitli Çocuk Hasta: Nadir Bir Sunum: Olgu Sunumu}

\section{Öz}

Lyme ilişkili üveit çoğunlukla erişkinlerde daha sık görülürken çocuklarda oldukça nadir görülmektedir. Oftalmolojik semptomlar, lyme vakalarının çok az kısmında görülmektedir. Üveit, lyme vakalarının\% 1'inden daha azında görülmektedir ve farklı klinik özellikler görülebilmektedir. Lyme ile ilişkili üveit tanısı için pozitif ELISA ve immunoblot serolojisi, ayırıcı tanıda diğer nedenlerin çeşitli testlerle dışlanması, tek başına verilen steroid tedavisine birincil dirençten sonra antibiyotiklerin etkinliği, kene 1sırığı, endemik alanda yaşamak ve sistemik klinik semptomların mevcudiyeti araştırılmalıdır. Bizim olgumuzda, 4 ay önce kene 1sırması öyküsü olan, pars planit ve periferik retina vasküliti tanısı konulan 11 yaşındaki erkek hastada çok nadir görülen Lyme hastalığına bağlı intermediate üveiti sunmayı amaçladık. Tedaviden sonra 6 ay asemptomatik kaldıktan sonra nüks gözlendi. Ancak olgumuz steroid tedavisine ek olarak yeni bir antibiyotik kürü ile başarıyla tedavi edildi.

Anahtar Kelimeler: Lyme hastalığı; çocuk; ara üveit.

\section{INTRODUCTION}

Lyme disease is a tick-borne multisystemic disease caused by the spirochete called Borrelia burgdorferi (1). Ophthalmological symptoms are extremely rare as they occur in less than $1 \%$ of Lyme cases (2). Conjunctivitis, episcleritis, neuroretinitis, retinal vasculitis, cranial nerve paralysis and uveitis have been shown in the literature as ocular involvement (3). Although it is a rare cause, it can cause any type of uveitis, and it is estimated to be less than $1 \%$ of all uveitis (4). Uveitis due to Lyme disease is more common in adults, while it is very rare in children (2-4). In our study, we aimed to present a very rare Lyme disease-related intermediate uveitis in an 11-year-old male patient who had a history of tick bite 4 months ago, and was diagnosed with pars planitis and peripheral retinal vasculitis. 


\section{CASE REPORT}

An 11-year-old male patient presented with the complaint of blurred vision in both eyes, and prominent in the left eye. The patient's corrected visual acuity was 20/20 in both eyes and intraocular pressure was within normal limits. In his biomicroscopic examination, both eyes had clear cornea, natural lens and sclera, no cells in the anterior vitreous and no posterior synechiae and there was no anterior chamber reaction. Dilated fundus examination revealed perivascular sheathing in the inferior quadrants of retina in the right eye, vitreous fibrin reaction, +3 cells in the left vitreous, snowball opacities in the periphery (pars planitis) and perivascular sheathing. In fundus fluorescein angiography (FFA), there was no capillary leakage of fluorescein in the any quadrants of retina in the right eye, but left intense retinal vascular and capillary leak (Figure 1A, B).

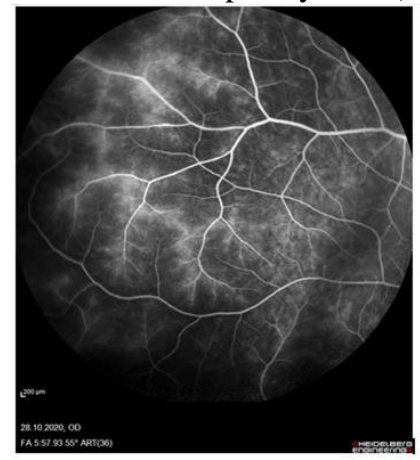

A
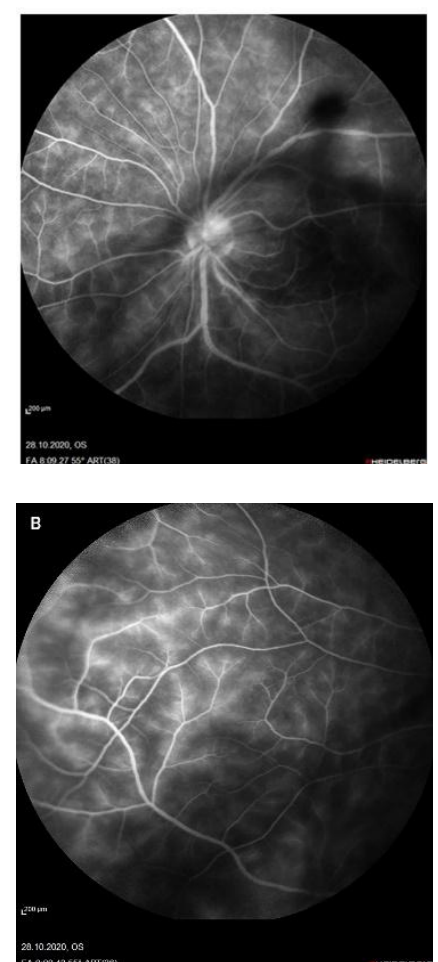

Figure 1. A.Capillary leakage of fluorescein in the inferior quadrants of retina in the left eye ,vitreous fibrin reaction, B. Snowball opacities in the periphery (pars planitis) and capillary leakage of fluorescein.

With these findings, the patient was diagnosed with pars planitis and peripheral retinal vasculitis. Fluorescein angiography revealed vascular leakage and hyperfluorescent foci in the optic disc and retina. In addition, Optical coherence tomography (OCT) was followed up from the beginning of his disease (Figure 2 A, B).



Figure 2. A, B: Initial and last OCT image A. Initial, B. The last OCT

In the detailed medical history of the patient, it was learned that he had been bitten by a tick approximately 4 months ago and then there were annular erythematous lesions on his chest and legs, but we learned that these lesions were ignored and the lesions regressed spontaneously (Figure 3A, B).

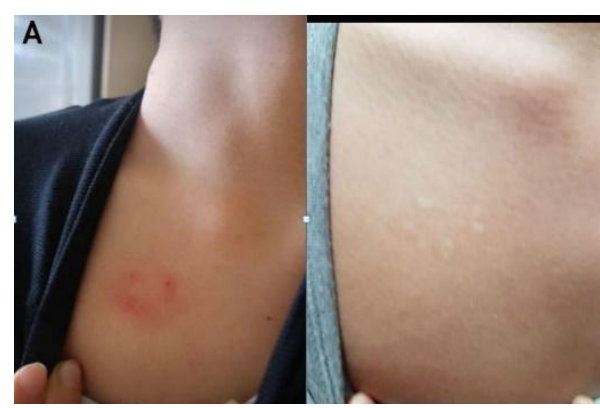

Figure 3A. Tick bite lesions (annular erythematous lesions on the chest after a tick bite 4 months ago, spontaneous regression of the lesion)

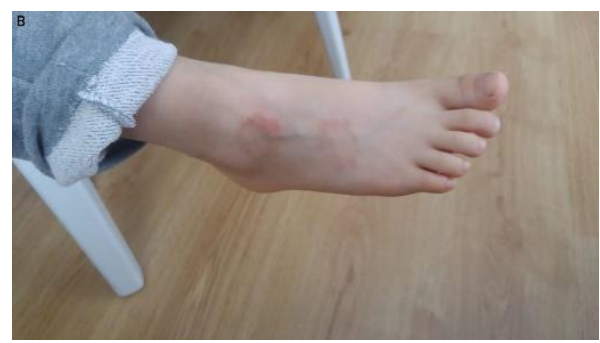

Figure 3B. Appearance of annular erythematous lesion on the foot and ankle 
Complete blood count, chest radiography, antinuclear antibody (ANA), lupus anticoagulant, liver enzymes, angiotensin converting enzyme (ACE), lysozyme, lipid panel, Purified Protein Derivative (PPD), VDRL, toxoplasma (Ig M, Ig G), HBs Ag, anti-HBV, anti HCV, anti HIV antibodies, HSV (Ig M,Ig G) and CMV (Ig M,Ig G), wright agglutination test was performed for vasculitis etiology. Results of the patient as ANA (0.3),HLA B27,PPD, anti CMV Ig M (0.12), Toxoplasma IgM 0.08 (0-0.6) U/mL, VDRL and ACE (30.1U/L) were negative, but serum B. burgdorferi serum IgG was found to be high (1/100) and immunoblot analysis was positive. Behcet's disease was evaluated and ruled out by dermatology and pediatric rheumatology for the differential diagnosis. Considering intermediate uveitis due to Lyme disease and intravenous Ceftriaxone $(500 \mathrm{mg} /$ day for 2 weeks) and orally steroid (30 mg/day) were started. Following this treatment, steroid was tapered as decreasing $5 \mathrm{mg}$ once a week. In the patient who was asymptomatic for six months after treatment recurrence was considered, as capillary leakage was observed to increase in the control FFA. However, our case was successfully treated with a new course of antibiotics in addition to steroid therapy. A written informed consent was obtained from the patient.

\section{DISCUSSION}

When eye involvement is presented in Lyme disease, symptoms such as conjunctivitis, photophobia, periorbital edema, cranial nerve palsy, keratitis, pupillary abnormalities, papill edema, optic neuritis, optic atrophy, and uveitis can be observed (3). Uveitis is seen in less than $1 \%$ of Lyme cases and presents with different clinical features (1). Bernard A et al. evaluated 1006 uveitis patients retropectively in their clinical spectrum study on lyme disease-associated uveitis, seven patients $(71.4 \%$ male, mean age $=53(38-70))$ had lymeassociated uveitis. Intermediate uveitis was detected in four patients, anterior in three and posterior in three. Most of them were unilateral $(n=6 ; 85.7 \%)$, one was granulomatous and two had synechiae. Four patients had peripheral retinal vasculitis (4). In another clinical spectrum study by Mikkilä $\mathrm{HO}$ et al., 4 patients had neuro-ophthalmological disorders, 5 patients had external ocular inflammation, 10 patients had uveitis, and 1 patient had branch retinal vein occlusion. In addition, it was reported that one patient developed episcleritis and one patient developed abducens palsy within 2 months after infection (1). In our case, there were perivascular sheathing in the retina of the right eye, vitreous fibrin reaction, +3 cells in the left vitreous, snowball opacities in the periphery (pars planitis) and perivascular sheathing.

In the literature, while Lyme-associated uveitis is more common in adults, it is extremely rare in children $(1,4$, 5). The mean age was 40.2 (14-70) in the study of Mikkilä HO (1) and 53 (38-70) in the study of Bernard A (4). In the study by Mikkilä $\mathrm{H}$ et al., only 1 patient out of 20 lyme-associated uveitis patients was under 18 years of age. (5). Unlike the literature our case was an 11-year old pediatric patient.

Ocular Lyme disease can affect the retinal arteries or veins at different levels (6). Arterial involvement includes sheathing, cottony spots, and occlusion, while venous involvement may include sheathing, retinal bleeding, edema, and retinal vein branch occlusion $(1,6)$. Although retinal vasculitis was previously reported in only a few Lyme borreliosis cases, it has been increasingly observed in recent years (1). In a retrospective study by Bernard A et al., peripheral retinal vasculitis was found in only 4 patients (7). Retinal vasculitis may develop around the macula or in the peripheral retina associated with anterior and / or posterior segment ocular inflammation $(6,8)$. In our case, on the right eye no vascular leak was observed but on the left eye intense vascular and capillary leak was detected. Vascular leakage and hyperfluorescent foci were detected in the optic disc and retina with fluorescein angiography.

Because the serological diagnosis of Lyme disease is difficult and its symptoms are not specific, it is very difficult to diagnose $(5,7,9,10)$. Indirect enzyme-linked immunosorbent test (ELISA), immunoblot analysis and PCR were examined in the diagnostic study of ocular Lyme borreliosis by Mikkila et al. They resulted that immunoblot analysis and PCR should be used in addition to $\operatorname{ELISA}(5)$. In a retrospective study conducted by Bernard et al., in 430 patients with uveitis, serum Ig G and IgM levels were measured by ELISA method. They concluded that the seroprevalence of B. burgdorferi was $7.9 \%$ among uveitis patients (7). In our study, only serum Lyme Ig $\mathrm{G}$ and immunoblot analysis were positive.

Although some findings in Lyme disease regress spontaneously, the risk of recurrence and more serious complications increases in cases where antibiotic treatment is not given (1). In a retrospective study on Lyme-associated uveitis conducted by Bernard A et al., uveitis due to Lyme disease was detected in 7 of 1006 uveitis patients who applied to their clinics between 2003-2016. They stated that 4 of these 7 patients recurred and also resulted that intravenous ceftiriaxone treatment was more effective. We applied systemic antibiotics and oral and topical steroids to our patient. Recurrence was observed after being asymptomatic for 6 months after the treatment. However, our case was successfully treated with a new course of antibiotics in addition to steroid therapy.

In conclusion, Lyme-associated uveitis is very rare in children. Uveitis due to Lyme disease should be kept in mind in the differential diagnosis of pediatric patients presenting with undisclosed uveitis. In addition, uveitis due to Lyme disease can progress with relapses and remissions.

Authors's Contributions: Idea/Concept: N.A.; Design: N.A.; Data Collection and/or Processing: N.A.; Analysis and/or Interpretation: N.A.; Literature Review: N.A.; Writing the Article: N.A.; Critical Review: N.A.

\section{REFERENCES}

1. Mikkila HO, Seppala IJ, Viljanen MK, Peltomaa MP, Karma A. The expanding clinical spectrum of ocular lyme borreliosis. Ophthalmology. 2000; 107(3): 5817. 
2. Kauffmann DJ, Wormser GP. Ocular Lyme disease: case report and review of the literature. $\mathrm{Br} \mathbf{J}$ Ophthalmol. 1990; 74(6): 325-7.

3. Lesser RL. Ocular manifestations of Lyme disease. Am J Med. 1995; 98(4): 60-2.

4. Bernard A, Seve P, Abukhashabh A, Roure-Sobas C, Boibieux A, Denis P, et al. Lyme-associated uveitis: Clinical spectrum and review of literature. Eur $\mathbf{J}$ Ophthalmol. 2020; 30(5): 874-85.

5. Mikkila H, Karma A, Viljanen M, Seppala I. The laboratory diagnosis of ocular Lyme borreliosis. Graefes Arch Clin Exp Ophthalmol. 1999; 237(3): 225-30.

6. Smith JL, Winward KE, Nicholson DF, Albert DW. Retinal vasculitis in Lyme borreliosis. J Clin Neuroophthalmol. 1991; 11(1): 7-15.

7. Bernard A, Kodjikian L, Abukhashabh A, RoureSobas C, Boibieux A, Denis P, et al. Diagnosis of Lyme-associated uveitis: value of serological testing in a tertiary centre. Br J Ophthalmol. 2018; 102(3): 369-72.

8. Kılıç Müftüoğlu İ, Aydın Akova Y, Gür Güngör S. A Case of lyme disease accompanied by uveitis and white dot syndrome. Turk J Ophthalmol. 2016; 46(5): 241-3.

9. Mikkila H, Seppala I, Leirisalo-Repo M, Karma A. The significance of serum anti-Borrelia antibodies in the diagnostic work-up of uveitis. Eur J Ophthalmol. 1997; 7(3): 251-5.

10. Caplash S, Gangaputra S, Kesav N, Akanda M, Vitale $\mathrm{S}$, Kodati $\mathrm{S}$, et al. Usefulness of routine lyme screening in patients with uveitis. Ophthalmology. 2019; 126(12): 1726-8. 